\title{
RESENHAS|REVIEWS
}

BOBBIO, Norberto. Da Estrutura à Função: novos estudos da teoria do direito. São Paulo: Manole, 2017.

\section{Normas Promocionais e Teoria Funcional do Direito}

\author{
Promotional Standards and Functional Theory of the LaW
}

\section{Luiz Gustavo Campana Martins ${ }^{1}$}

Como citar: MARTINS, Luis Gustavo Campana. Normas promocionais e teoria funcional do direito. Scientia Iuris. Londrina, v. 24, n.2, p. 189-193, jul. 2020. DOI: 10.5433/2178-8189.2020v2 4n2p189. ISSN: 2178-8189

Resumo: A tradicional concepção protetora e repressiva do direito não mais dá conta de explicar a realidade, que sofreu uma transformação radical. Essa mudança se deu pela transição do Estado liberal puro para um Estado de bem-estar social, o chamado Welfare state. Bobbio esclarece que antes o direito estava preso à imagem de um Estado que estabelecia regras e um árbitro, portanto também preso a uma atuação sancionadora e coativa. O papel do direito na sociedade sempre foi aquele de proteger determinados interesses mediante a repressão dos atos desviantes - a partir de sanções negativas. Contudo, com as novas exigências do Estado assistencial, o direito passa não mais apenas a tutelar os atos conformes, mas também a estimular atos inovadores, a partir das normas promocionais.

Palavras-chave: Normas Promocionais. Teoria Funcional do Direito. Sanção Positiva.

Abstract: The traditional protective and repressive conception of law can no longer explain the reality, which has undergone a radical transformation. This change came about through the transition from a pure liberal state to a welfare state called the welfare state. Bobbio clarifies that before the law was tied to the image of a state that set rules and an arbitrator, therefore also bound to a sanctioning and coercive action. The role of law in society has always been that of protecting certain interests by repressing deviant acts - from negative sanctions. However, with the new requirements of the welfare state, the law no longer only protects compliant acts, but also encourages innovative acts, based on promotional norms.

Keywords: Promotional Standards. Functional Theory of Law. Positive Sanction.

Para compreender a obra Da estrutura à função, referência-chave para este capítulo, é preciso antes compreender a evolução do pensamento de Norberto Bobbio, mais precisamente como se deu a sua relação com os paradigmas positivista e jusnaturalista, a fim de visualizar, de melhor forma, a transição de sua análise estruturalista para a funcionalista do direito. Assim, algumas considerações de Mario Losano, referentes ao prefácio à edição brasileira, serão

\footnotetext{
1 Mestrando em Direito Negocial pela Universidade Estadual de Londrina (UEL). Especialista em Filosofia Política e Jurídica pela Universidade Estadual de Londrina. Bacharel em Direito pelo Centro Universitário Filadelfia (UNIFIL). E-mail: gus.campana@hotmail.com.
} 
pontuadas a seguir.

Pensador do século XX, Norberto Bobbio trouxe grandes contribuições acadêmicas que giram em torno da função promocional do direito. Sua trajetória na filosofia do direito e, mais adiante, como professor de filosofia política na Universidade de Turim, Itália, foi fundamental para a construção de seu pensamento.

Pode-se dizer que Bobbio teve sua maior aproximação com o positivismo jurídico eminentemente uma relação com Hans Kelsen - entre as décadas de 1950 e 1970, e depois, na década de 1980, se afasta desse paradigma para ir de encontro à análise da função do direito.

Bobbio começa, a partir da década de 1950, a ler os autores críticos de Hans Kelsen, sendo que vai publicar em 1967 um ensaio que traz uma primeira revisão crítica que o próprio autor dirige à teoria pura do direito de Kelsen. Embora nessa época o autor ainda fosse fiel às considerações de uma teoria pura, ele admitia que uma mudança progressiva de paradigmas era saudável e que queria favorecê-la.

A tradicional concepção protetora e repressiva do direito não mais dá conta de explicar a realidade, que sofreu uma transformação radical. Essa mudança se deu pela transição do Estado liberal puro para um Estado de bem-estar social, o chamado Welfare state. Antes, o direito estava preso à imagem de um Estado que estabelece regras e um árbitro, portanto também preso a uma atuação sancionadora e coativa. Bobbio $(2017$, p. 2) busca, então, examinar as novas técnicas de controle social, no contexto do Estado social, para uma teoria geral do direito.

Entre as modalidades de controle social, Bobbio estuda o emprego cada vez mais difundido de técnicas de encorajamento e acréscimo - sanções positivas - em detrimento das técnicas de desencorajamento - sanções negativas.

Convém distinguir as normas positivas e negativas de um lado, das sanções positivas e negativas de outro. Essa relação entre normas e sanções pode se dar por qualquer combinação: uma norma positiva pode ter uma sanção positiva ou negativa, e assim por diante. Normas são comandos, de dar ou fazer, e proibições, enquanto que sanções constituem prêmios ou castigos (BOBBIO, 2017, p. 6).

NoEstado assistencial contemporâneo, as técnicas de encorajamento se dão majoritariamente por normas positivas, em que pese também acontecer pelas negativas. Para sintetizar, Bobbio (2017, p. 13) sistematiza quatro as possíveis situações: a) comandos reforçados por prêmios; b) comandos reforçados por castigos; c) proibições reforçadas por prêmios; d) proibições reforçadas por castigos.

Embora não exista uma regra, os comandos estão mais ligados às premiações e as proibições aos castigos. Também essa classificação vale, ainda que de forma mais rara, para as omissões, e não apenas para as ações.

Bobbio (2017, p 14) diz que o Estado contemporâneo, marcado pelas normas de organização, não coloca em crise, necessariamente, a imagem do Estado protetor-repressivo. Essa desconstrução - do modelo de estado - ocorreria naturalmente a partir do uso frequente das técnicas de encorajamento. O uso dessas técnicas leva, com o tempo, à passagem do direito como 
ordenamento protetor-repressivo para o ordenamento como função promocional.

Convém aqui, fazer uma distinção dos modelos filosóficos de constituições. Nos ordenamentos liberais clássicos a principal função do estado é a de tutelar, são normas garantistas, que pressupõem medidas autoritárias e coercitivas. Já nos pós-liberais, a função é a de promover, são normas promocionais; pressupõem medidas de estímulo ou incentivo.

A técnica de encorajamento consiste, portanto, em promover comportamentos desejados. Nessa categoria geral, é possível distinguir dois expedientes: de facilitação, que deixa menos onerosa a operação; e de sanção positiva, que busca tornar a operação mais atraente, com prêmios, isenções. O primeiro se dá, por exemplo, nos casos de subvenção, ajuda ou contribuição financeira, facilitação de crédito. O segundo, por exemplo, ocorre na consignação de um prêmio para um comportamento superconforme ou em uma isenção fiscal. Enquanto que as técnicas de desencorajamento consistem em reprimir comportamentos não desejados, através de leis sancionatórias (BOBBIO, 2017, p. 17-20).

O papel do direito na sociedade sempre foi aquele de proteger determinados interesses mediante a repressão dos atos desviantes - a partir de sanções negativas. Contudo, com as novas exigências do Estado assistencial, o direito passa não mais apenas a tutelar os atos conformes, mas também a estimular atos inovadores.

Com isso, as sanções positivas começam a se destacar perante o ordenamento. Procurase então incentivar as técnicas de estímulo aos comportamentos úteis, ou desejáveis, ao invés de reprimir os atos considerados nocivos (BOBBIO, 2017, p. 24).

Com o advento da sociedade industrial, o direito passa a ser secundário para a tratativa dos fenômenos sociais, passa a ser visto com desconfiança quando se fala em mecanismo de mudança social. Nesse sentido, cresce a importância das ciências sociais, pois estas têm um potencial preventivo das ações não desejadas, para que não seja necessário recorrer às reparações - papel do direito. (33-36)

Bobbio já intui no sentido de que quando o direito começa a sentir necessidade de se aproximar das ciências sociais significa que a sociedade está passando por um período de profundas transformações sociais. Tendo em vista essa aproximação, é cada vez mais necessário que também o jurista se aproxime dos cientistas sociais. $\mathrm{O}$ jurista parte da regra para determinar se o comportamento é lícito ou ilícito, enquanto que o sociólogo parte do comportamento para chegar à regra que pode explicá-lo (BOBBIO, 2017, p. 46-51).

O jurista, segundo Bobbio, pode ter duas funções típico-ideias: intérprete ou pesquisador. Como intérprete, é um conservador e transmissor de um corpo de regras já dadas, de que é o depositário e guardião. Como pesquisador, o jurista é criador, ele mesmo, de regras que transformam o sistema dado, do qual não é mais apenas receptor, mas também colaborador ativo e, quando necessário, crítico (BOBBIO, 2017, p. 46-51).

Nesse sentido, o ordenamento deve ser compreendido como um sistema aberto, sendo que nele "a maioria das regras estão, ou são consideradas, em estado fluido e em contínua transformação" (BOBBIO, 2017, p. 38). Complementa ainda o autor dizendo que 
Essa nova construção do papel do jurista, aliada à função do direito em um ordenamento de sistema aberto, coloca em crise o paradigma do positivismo. Este paradigma sempre assumiu a lei, quase que exclusivamente, como fonte do direito. No novo cenário, abre-se margem para novas fontes extralegislativas, como princípios e costumes, que incentivam a atividade criadora do juiz.

A partir desse cenário, Bobbio coloca algumas tendências que podem constatar toda essa transformação que vem acontecendo no universo jurídico: (1) o progressivo aumento das normas de organização em detrimento das normas de conduta; (2) a passagem de um controle social fundado predominantemente sobre normas providas de sanção para um controle de normas técnicas; e (3) a passagem da função tradicional repressiva do direito para a função promocional (BOBBIO, 2017, p. 43-44).

Olhando para a história, sob a perspectiva das teorias das ciências sociais, não há dúvida de que a abordagem estruturalista sempre prevaleceu à funcionalista. "Em poucas palavras, aqueles que se dedicaram à teoria geral do direito se preocuparam muito mais em saber 'como o direito é feito' do que 'para que o direito serve'." (BOBBIO, 2017, p. 53).

Bobbio discorda de Kelsen pois, para este, uma teoria científica não deve se ocupar da função do direito, mas tão somente de seu aspecto estrutural; não deve considerar o objetivo a ser perseguido ou alcançado, mas apenas o ordenamento em si mesmo (BOBBIO, 2017, p. 54).

Uma diferença entre Kelsen e Bobbio está quanto ao entendimento do direito em relação à estrutura. Para Kelsen, o direito tem uma estrutura própria, distinta de outros sistemas isso implica na separação entre estrutura e função. Para Bobbio, o direito é uma estrutura das relações sociais - isso implica em uma confusão entre estrutura e função, uma não pode ser entendida fora da outra.

Bobbio (2017, p. 53-79) faz, então, algumas ponderações acerca da teoria pura. Segundo ele, Kelsen entende o direito enquanto um ordenamento coativo. Nesse viés, o direito é um meio e não um fim em si mesmo. Ele, como meio, tem sua função de garantir a consecução dos fins que não podem ser garantidos por outras formas de controle social. Ou seja, o direito atende aos fins determinados pelo grupo social que o controla; funciona como organizador dos meios para a perseguição dos fins definidos por tais grupos.

A tese de Kelsen é, por excelência, a tese o positivismo. Ele entende o direito como uma técnica específica de organização social, sendo que esse controle se dá pela coação, ou seja, pelo uso de sanções negativas.

De forma simples, Bobbio considera que a concepção tradicional Kelseniana entende o Estado como entidade organizadora do aparato coativo, que age através de ameaças, desencorajamento e utilização de sua função repressiva. Por outro lado, na concepção funcionalista de Bobbio, o Estado de Direito é teleológico e deve tutelar as liberdades fundamentais; é um Estado assistencial que age por promessas e encorajamento, assumindo sua função promocional.

A função promocional do direito pode ser exercida por dois diferentes expedientes: 
incentivos e prêmios. Incentivos são medida que servem para facilitar o exercício de uma determinada atividade econômica - expediente para obter uma ação boa. Prêmios são medidas que visam a oferecer uma satisfação àqueles que já tenham realizado determinada atividade resposta a uma ação boa. Essa distinção é necessária para entender-se que apenas os prêmios são classificados como sanções positivas (BOBBIO, 2017, p. 71-72).

A concepção Kelseniana de Estado e de Direito, enquanto agentes coatores, é colocada em crise pelo espaço que passa a ocupar o direito promocional, no cenário do Estado assistencial.

O Estado visto exclusivamente como organizador da força passa a ser contestado cada vez mais, na medida em que aumenta sua intervenção no domínio econômico. Essa intervenção passa a colocar o Estado também no papel de organizador das relações sociais, das estruturas e da própria economia, sendo que essa organização se dá, cada vez mais, por técnicas de promoção, incentivo, estímulo, em detrimento das técnicas tradicionais de repressão, ameaça, desencorajamento.

É de todo esse conjunto de análise, portanto, que Bobbio tira a inspiração que o permite definir, em poucas palavras, o Direito: "Creio, portanto, que hoje seja mais correto definir o direito, do ponto de vista funcional, como forma de controle e de direção social. ” (BOBBIO, 2017, p. 79).

Como citar: MARTINS, Luis Gustavo Campana. Normas promocionais e teoria funcional do direito. Scientia Iuris. Londrina, v. 24, n. 2, p. 189-193, jul. 2020. DOI: 10.5433/2178-8189.2020v2 4n2p189. ISSN: 2178-8189 